\title{
EL PATRONATO REAL EN CATALUÑA:
}

\section{5-1775}

\section{Antonio CARRASCO RODRÍGUEZ}

Universidad de Alicante.

El advenimiento de la dinastía borbónica, a comienzos del siglo XVIII, supuso un cambio considerable en las directrices generales de la política de la monarquía hispánica, puesto que a raíz de los Decretos de Nueva Planta, las particularidades de las "naciones" que la componían desaparecieron casi por completo (con la excepción de Navarra y las Provincias Vascongadas), siendo sustituidas por un exaltado centralismo. Para lograr consolidar y extender su autoridad, los reyes se marcaron el objetivo de dominar todos los resortes del poder.

Y como a nadie escapaba la enorme influencia que la Iglesial tenía sobre el católico pueblo español, desde los primeros años de la centuria los monarcas fijaron como una de sus metas prioritarias el control de tan grande y poderosa institución, aunque ello supusiera enemistarse con la Santa Sede.

Los monarcas hallaron en la regalía del Real Patronato la forma de intervenir en la Iglesia de sus reinos, para convertirla en un instrumento que les permitiera o, al menos, les facilitara el llevar a cabo sus reformas.

El Patronato Real presentaba tres diferentes facetas que legitimaban la intervención real en los asuntos eclesiásticos, siempre que fueran de carácter temporal, pues nadie osaba discutir el hecho de que los asuntos espirituales, de doctrina, fueran competencia exclusiva del papa. Dos de ellas pueden considerarse derechos muy ventajosos para la corona, y la otra, una obligación gustosa. Los derechos aludidos son, por un lado, la provisión de los beneficios pertenecientes al Real Patronato, y por otro, la carga a modo de pensiones de una determinada cantidad de las rentas de tales prebendas, que generalmente solía hacerse coincidir con el tercio de su "valor líquido". La obligación hace referencia a la percepción que los monarcas españoles tenían de sí mismos desde los tiempos del Concilio de Trento; se consideraban patronos de las iglesias nacionales y, como tales, tenían que protegerlas y mantenerlas. 
Antes de comenzar el análisis en profundidad de cada uno de estos aspectos, haremos una breve reseña de las fuentes utilizadas para la confección del presente trabajo de investigación. Unas fuentes que, a pesar de su importancia para el conocimiento de las relaciones entre la Iglesia y el Estado en la centuria de las Luces, no habían sido analizadas con anterioridad, quizá debido a su riqueza, volumen y complejidad.

Los fondos documentales manejados se hallan en el Archivo Histórico Nacional, y fueron expedidos por la cuarta de las secretarías de la Cámara de Castilla, la de Gracia, Justicia y Real Patronato de la Corona de Aragón?2.

$\mathrm{Al}$ considerar que el estudio de la ingente masa documental excedía las pretensiones de realizar una memoria de licenciatura, orienté mis primeros esfuerzos hacia una selección de aquellas series que permitiesen una mejor aproximación al contenido general y a la concreción de ulteriores líneas de trabajo. Afortunadamente, hallé los libros de la serie "Registros del Real Patronato". Tras una primera cata, comprobé que recogían todas las disposiciones tomadas en la Cámara concernientes al Real Patronato en la Corona de Aragón, siguiendo un orden cronológico. Asimismo, pude observar que los libros que trataban sobre Cataluña (cuya numeración iba del 280 al 284) eran los que ofrecían una información más completa e interesante.

$\mathrm{Y}$ pese a reducir el ámbito de estudio del Real Patronato al Principado de Cataluña, me vi en la necesidad de delimitar la magnitud temporal. Puse el tope en el año 1775, haciendo llegar el estudio hasta el inicio del último cuarto de siglo. Motivó mi decisión el hecho de que, tras dicha fecha, la mayor parte de los documentos no aportaba ya novedades destacables. La lectura de D. Antonio Domínguez Ortiz reforzó mis convicciones: "Las grandes reformas de la época de Carlos III, en las que la Iglesia debía participar como sujeto activo y pasivo, sufrieron una desaceleración muy marcada en la segunda mitad de aquel reinado, porque el monarca era, en el fondo, mucho más conservador que sus ministros"3.

Como ya se indicó, el monarca, en virtud de su Real Patronato, tenía el derecho de proveer determinadas piezas eclesiásticas, tanto seculares como regulares. No obstante, no sólo podía realizar los nombramientos de aquellos beneficios fundados, erigidos y dotados por él mismo, o sus predecesores en la corona. Una serie de recursos le permitían acceder a la provisión de otras prebendas.

El más útil de estos recursos fue el derecho de resulta. Era ejercido por el rey cuando, tras adjudicar un beneficio del Real Patronato a un eclesiástico que detentaba otra prebenda que no lo era, procedía a proveer dicha pieza vacante. Mediante este sistema, la provisión de una pieza eclesiástica podía generar toda una cadena de nombramientos de clérigos para beneficios que, de cualquier otra manera, hubieran quedado al margen de sus prerrogativas.

Asimismo, la corona se aprovechó de la coyuntura política para proceder al nombramiento y provisión de ciertos beneficios eclesiásticos que, siendo de patronato particular -secular o regular-, se agregaron a la monarquía al confiscar ésta los bienes de sus legítimos propietarios por militar en las filas austracistas ${ }^{4}$. 
Aún se sirvieron los monarcas de otro artificio para poder, si no elegir directamente y según su voluntad a los beneficiados, al menos, controlar, mediante su confirmación, los nombramientos de determinadas piezas eclesiásticas: los beneficios simples pertenecientes a los donatarios de la Corona -que disponían de ellos en virtud de cualquier donación real-5.

La complejidad era la nota más característica del proceso de provisión de beneficios eclesiásticos. Ello se debió, entre otros factores, a la complicación burocrática, y a la gran cantidad y variedad de piezas eclesiásticas a cubrir, especialmente tras la transacción del Concordato con la Santa Sede en 1753 -y la consiguiente extensión del Patronato Real-, pues sobre la Cámara se volcó el "cuerno de la abundancia beneficial", y durante mucho tiempo sus oficinas se vieron desbordadas 6 .

Si recreamos dicho proceso comprenderemos el porqué de dicha complicación burocrática.

Tras quedar vacante un beneficio eclesiástico del Patronato Regio, cl obispo de su diócesis -si era secular-, o el abad de su monasterio -si era regular-, debían remitir al rey por medio de la Cámara un informe con la causa de la vacante y las características de la prebenda (valor y calidades; cargos, pensiones y otras obligaciones).

Una vez conocida la vacante por el rey, éste sometía su provisión a la consulta de la Cámara. En ella, dicho organismo elevaba al rey su opinión sobre el asunto, opinión que normalmente era unánime 7 . Y a partir de tal recomendación, el monarca tomaba la decisión de proveer a un determinado clérigo. Después de hecha la elección, devolvía la consulta con su resolución a la Secretaría de la Cámara, para que la hiciera pública.

Una vez conocida por el beneficiado, éste -o su agente- debían acudir a dicha secretaría a solicitar la cédula de presentación, llevando una certificación de su prelado, en la que se hicieran constar los beneficios y rentas que detentara, y su posible compatibilidad con la nueva provisión. En el caso de que fueran incompatibles, el monarca quedaba en la facultad de proveerlos, ejerciendo el derccho de resulta.

El provisto pasaba luego a la oficina del sello, donde registraban el título, con cl que el candidato podría recoger definitivamente la prebenda que le había correspondido, una vez que ésta viniera confirmada desde Roma.

De obtener dicha confirmación se ocupaban las agencias de preces. La de Madrid enviaba a la de la Ciudad Eterna la lista de prebendas que requerían las bulas pontificias. Allí, el propio agente de preces o el embajador en dicha corte presentaban las elecciones reales ante "Su Beatitud", para que les diera su confirmación ordenando la expedición de las bulas correspondientes, cuyas tasas había que pagar en la Dataría.

Satisfechos los pagos, los escritos pontificios iban a manos del agente de preces en Roma, que los remitía a la agencia de Madrid. Después, pasaban a manos del secretario de la Cámara, que los dejaba al fiscal para su supervisión, por si venían en la debida forma o en ellos había algo contrario a las regalías de la corona. 
Salvado este obstáculo, se le entregaba la bula al beneficiado, que disponía de un determinado plazo de tiempo -normalmente dos meses- para presentarse en su beneficio y tomar posesión de él.

Al mismo tiempo, contando con el visto bueno definitivo del fiscal, y por orden del rey, la Cámara expedía unos despachos llamados executoriales, en los que se advertía tanto a las autoridades seculares como a las eclesiásticas del reino en que se hallase la referida prebenda -en nuestro caso, el Principado de Cataluña- para que no se le "embarazara" al beneficiado el acceso a la posesión de ella.

Y así terminaba el proceso de provisión de beneficios eclesiásticos del Real Patronato. El provisto se presentaba en su beneficio con los documentos pontificios y las cartas ejecutoriales, y normalmente no había problemas para que tomara posesión de él.

Antes de pasar al análisis concreto de la provisión real de los beneficios eclesiásticos catalanes, es necesario realizar una precisión fundamental. El factor de mayor influencia en esta materia fue la actividad del Confesor Real. Puede afirmarse, sin temor a exagerar, que el Padre Confesor formaba parte del "equipo ministerial", porque en la práctica ejercía el papel de ministro de asuntos eclesiásticos. Por las manos de dicho personaje pasaban casi todos los negocios eclesiásticos del reino, y las provisiones no fueron la excepción a la regla. Más bien, fueron uno de sus principales negocios. En ellas, su poder era decisivo puesto que normalmente era él quien confería las piezas eclesiásticas, limitándose el monarca a dar su "visto bueno"8.

La provisión real de beneficios regulares, se centró en torno a tres órdenes religiosas: la Premonstratense, la Cisterciente y, sobre todo, la Benedictina Claustral.

En el Principado, los monarcas españoles tuvieron la facultad de intervenir en la provisión de los abades del venerable monasterio premonstratense de Santa María de Bellpuig de las Avellanas, que fue cuna de grandes figuras de la cultura del Siglo de las Luces. En virtud de una concordia firmada en 1682 entre Carlos II y el monasterio, y confirmada por bulas pontificias, la provisión de la abadía pasó de ser vitalicia a trienal, corriendo a cargo del rey la elección del abad entre los componentes de una terna que proponían el abad y el cabildo de aquella casa. El acuerdo estipulaba, además, que ningún miembro del monasterio pudiera gobernar la abadía dos trienios consecutivos.

Cuatro monasterios pertenecían a la Orden Cisterciense en Cataluña. Dos de ellos no fueron provistos por el rey, pese a que, a lo largo de la centuria, y tras investigaciones sobre su fundación, la monarquía los reconoció como pertenecientes a su Real Patronato. Estos fueron los monasterios de Nuestra Señora de Poblet, y de Santas Cruces. Las otras dos comunidades monásticas, esto es, las abadías de Escarpe y Santa María de Labaix (en la diócesis de Lérida), sí fueron provistas por los diferentes monarcas. Una concordia firmada con Felipe IV y establecida según real cédula de 23 de agosto de 1649 definía el sistema de provisión. Los abades eran elegidos por el rey, tras el examen y consulta de la Cámara, cada cuatro años, entre los religiosos de los monasterios de la Congregación propuestos en terna por el vica- 
rio general y los definidores de la misma. Otra peculiaridad de la Congregación Cisterciense era que cuando concluía el cuatrienio del vicario general, sí éste era al mismo tiempo abad de algún monasterio de la orden, había de nombrarse un administrador para este monasterio.

Pero el grueso de provisiones reales en cuestión de beneficios regulares catalanes afectó a los monasterios de la Orden de "San Benito de los Claustrales", de la Provincia Tarraconense Caesaraugustana. En el Principado, las doce fundaciones benedictinas claustrales se hallaban repartidas por tres diócesis. En la de Barcelona: San Cugat del Vallés, San Pablo del Campo y San Pedro de la Portella, y Santa María de Serrateix. En la de Urgel: Santa María de Gerri. Y en la de Gerona, las ocho restantes, esto es: Santa María de Amer y Rosas, San Pedro de Besalú, San Pedro de Camprodón, San Esteban de Bañolas, San Pedro de Galligans, Santa María de Ripoll, San Pedro de Rodas y San Salvador de Breda. Ante cualquier vacante -bien por fallecimiento, bien por ascenso del prelado-, y en todo momento, los monarcas pudieron proveer incondicionalmente estas abadías. Además, puesto que casi siempre los nombramientos recaían en eclesiásticos de los monasterios de la misma Congregación, dichas promociones permitían a los reyes proveer los oficios que éstos ocupaban antes de la nominación, ejerciendo el derecho de resulta. Este modo de proceder permitió a la corona crear sólidos lazos de interdependencia, extendiendo por los cargos principales de dichas instituciones (limosneros, enfermeros, pavordes, obreros, despenseros, camareros, chantres, etc.) a sus adeptos.

A la hora de analizar la provisión real de los beneficios seculares del Principado es conveniente establecer una doble categorización. Por un lado, podemos diferenciar cuatros tipos de piezas eclesiásticas: las mitras, las dignidades y canonjías capitulares, los prioratos y arciprestazgos de las Iglesias Colegiales rurales, y por último, una larga serie de beneficios simples, curatos, capellanías y rectorías extracapitulares. Por otro lado, también aparece como necesario distinguir las diferentes prebendas por diócesis.

Las piezas más importantes desde todos los puntos de vista fueron las ocho mitras, es decir, el arzobispado de Tarragona, y los obispados de Barcelona, Gerona, Lérida, Solsona, Tortosa, Urgel y Vic. El rey podía proveerlas a su gusto gracias a la bula concedida a Carlos I por el papa Adriano VI el 6 de septiembre de 1523. Dicho escrito apostólico otorgaba a la corona el derecho de presentación de todas las catedrales y beneficios consistoriales de España. El nombramiento real de los obispos permitió a los monarcas acrecentar su control sobre ellos, utilizándolos como instrumento para poder llevar a cabo su política reformista.

Dentro de casi todos los cabildos catedralicios, la corona disponía de una o varias piczas eclesiásticas. Haciendo un breve repaso, observamos que en la Catedral de la Ciudad Condal, los reyes podían proveer las dignidades de tesorero, arcediano de Lobregat y arcediano de Badalona, así como dos beneficios, el llamado segundo de S. Blas, y el de Santa Espina en la capilla del Santo Sepulcro. En las catedrales de Gerona y de Vic, el deanato. En la Santa Iglesia Catedral de Lérida, la dignidad de 
maestrescuela, a la que iba unido el cargo de cancelario de la Universidad literaria de Cervera. Y en la de Solsona, cuatro dignidades: arcediano, deán, tesorero y chantre.

Igualmente, también proporcionaban bastante poder y riquezas al Regio Patronazgo los prioratos y arciprestazgos de algunas Iglesias Colegiales. En la diócesis de Gerona, el arciprestazgo de la Iglesia Colegial de Santa María de la villa de Villabeltrán. En la de Vic, los arciprestazgos de las Colegiales de San Juan de las Abadesas, y de Nuestra Señora de Estany. Y en la urgelitana, los prioratos de las Colegiales de Santa María de Meyá, y de San Pedro de Burgal, y el arciprestazgo de la Colegial de San Pedro de la villa de Ager.

Completaban la nómina de prebendas pertenecientes al Real Patronato catorce beneficios simples, rectorías, capellanías o curatos, distribuidos de la siguiente manera: seis en el obispado de Gerona ${ }^{9}$, cuatro en el de Lérida ${ }^{10}$, dos en el de Barcelona ${ }^{11}$, y uno en los de Torlosa' ${ }^{12}$ y Urgel ${ }^{13}$.

Además de esta serie de piezas eclesiásticas provistas por el rey gracias a su pertenencia al Patronato Real, el rey accedió a otras muchas por medio de los sistemas anteriormente mencionados (provisión de beneficios confiscados a austracistas, ejercicio del derecho de resulta -aunque el uso de éste fue ligeramente menor y, desde luego, tuvo menores repercusiones que en el caso de su aplicación a los beneficios regulares-).

Como anticipábamos, el segundo derecho útil para los intereses de la monarquía, en relación con el Real Patronato, radicaba en la disposición de una parte de las rentas de la Iglesia. En el siglo XVIII, la Iglesia era la institución más rica del reino. Los mismos economistas españoles de aquel tiempo tenían conciencia de que la Iglesia había venido disfrutando de una situación privilegiada y era dueña de una parte importantísima de la fortuna nacional ${ }^{14}$. Y dentro de la estructura de la Iglesia, las mitras y, en menor medida, los monasterios más poderosos, recogían y canalizaban hacia variados fïnes una parte importante de la riqueza del país (acumulación de bicnes inmuebles -tierras- en manos muertas, el "esplendor del culto", caridad y benefi(encia) ${ }^{15}$.

De cualquier forma, no todas las mitras vivían en la opulencia. Los contrastes entre las rentas de los obispados eran muy acentuados. En el Principado, mientras los de la Cataluña rural podían considerarse entre los más pobres de la península (junto a los gallegos -exceptuando Santiago-, y los aragoneses -salvo Zaragoza-), los de la costa disfrutaban de rentas considerables, aunque nunca comparables a las de los más ricos, los arzobispados de Toledo, Sevilla y Valencia ${ }^{16}$.

El conocimiento real de los ingentes recursos eclesiásticos se tradujo en un declarado interés por incrementar su participación en ellos. El rey obtenía por derecho una parte de las rentas y beneficios eclesiásticos por medio de una serie de impuestos especiales, como la mesada y la media annata, y recibía la renta de todos los beneficios que quedaban vacantes por muerte o traspaso de sus titulares (espolios y vacantes) ${ }^{17}$. Otros impuestos reales sobre la Iglesia (el escusado y el subsidio) aumentaban la Hacienda estatal, así como también el derecho de la Corona a recibir 
dos novenas partes del total recaudado por el pago de los diezmos ${ }^{18}$. Asimismo, el afán estatal por incrementar su participación en las rentas de la Iglesia española explicó las seculares disputas con la Santa Sede en pos del Real Patronato Universal, con el fin de encauzar hacia el real tesoro las sumas enormes que iban a desembocar a Romai9.

Los monarcas españoles también tenían acceso a las rentas de las mitras y abadías principales puesto que la Santa Sede les había atribuido la potestad de cargar pensiones hasta por un tercio de su valor líquido. Esta fracción se reducía a un cuarto en las que tenían menos disponibilidades ${ }^{20}$. Sólo las más pobres quedaban exentas de esta carga.

Aunque habitualmente el tercio era respetado por el rey ${ }^{21}$, en algunas ocasiones, la cantidad cargada era mayor. Ello se producía cuando las pensiones consignadas por bulas apostólicas excedían la cantidad mencionada 22 , por haber bajado las rentas del obispado.

En Cataluña, todas las mitras fueron cargadas con pensiones de designación real. Lo mismo les ocurrió a algunos de los monasterios de la Congregación Benedictina Claustral Tarraconense Caesaraugustana. En la diócesis de Urgel, al de Santa María de Gerri. En la de Barcelona, al de San Cugat del Vallés. Y en la de Gerona, a los de San Pedro de Camprodón, San Pedro de Besalú, San Pedro de Galligans, San Esteban de Bañolas, San Salvador de Breda y Santa María de Ripoll.

El organismo competente en la concesión de pensiones era la Cámara de Castilla, puesto que también era atribución suya la presentación de prelados ${ }^{23}$. Normalmente, a la muerte de un obispo, el cabildo eclesiástico o cl vicario de la diócesis notificaba la vacante al rey. La Cámara solicitaba un detallado informe sobre las rentas de la mitra para ver qué pensiones estaban ya consignadas y qué pensiones podía cargar el rey, dentro de los límites del tercio estipulado. La valoración se efectuaba por quinquenios para tener un valor medio aproximado y eliminar las diferencias anuales, a veces muy marcadas, pues siendo de ordinario los diezmos el factor principal de recaudación, estaban fuertemente influidas por la variabilidad característica de las cosechas ${ }^{24}$. La guerra, con sus consecuencias, también podía sumarse como factor distorsionador de estas valoraciones, a menudo provocando una cierta inflación de las rentas, meramente coyuntural25.

Una vez revisado el informe por la Cámara, se notificaba al rey la cantidad disponible para nuevas pensiones, cantidad que éste repartía entre los nuevos beneficiados.

Después, el obispo electo debía dar su consentimiento a todas las pensiones cargadas en el tercio real, tanto a las viejas como a las nuevas. Ello era un requisito previo inexcusable para la presentación regia.

Sólo entonces, se producía la presentación real ante el papa. Se remitían a la Curia tanto la cédula de presentación del nuevo prelado como la lista o "fe" de pensiones cargadas sobre las rentas de esa mitra. 
En el caso de quedar vacante alguna de las pensiones "viejas" consentidas antes de que la Curia pasase la gracia del obispado -antes de llegar las bulas de confirmación del nombramiento-, el rey podía volver a cargar la cantidad libre hasta el límite marcado, de modo que la nueva o nuevas pensiones se comenzarían a cobrar, al igual que las demás, desde la fecha en que se pasase la gracia de dicha mitra.

Los beneficiados con pensiones reales también debían conseguir las bulas pontificias de confirmación para hacerlas efectivas. Para ello disponían del plazo de un año, pasado el cual, si no las habían conseguido, quedaban de nuevo a la libre disposición del monarca.

Los beneficiarios de las pensiones tenían que cumplir una serie de requisitos. Debían ser españoles, pues por pragmática de 20 de noviembre de 1539 se prohibía que los extranjeros gozaran de pensiones cargadas sobre los beneficios "de estos reinos", y que los obtentores de beneficios consintieran que éstas se cargaran sobre foráneos ${ }^{26}$. También quedaba terminantemente prohibido que los naturales recibicran pensiones "para acudir con ellas á extrangeros", a modo de testaferros ${ }^{27}$. Tampoco podían recaer pensiones sobre sujetos menores de 18 años o que no tuvieran una conocida determinación de dedicarse al estado eclesiástico ${ }^{28}$.

Las pensiones estaban gravadas con una carga porcentual por el subsidio y el escusado que pesaban sobre todas las rentas de la Iglesia. Pero lue práctica común entre los prelados el que hicieran más descuentos que éstos en el pago de las pensiones. A ello responde la publicación por Fernando VI del real decreto de 7 de junio de 1746, en el que se fijan los modos que debían seguir los obispos en el pago de éstas ${ }^{29}$.

Tras la publicación del real decreto, el rey escribe cartas al arzobispo de Tarragona y a los obispos de Barcelona, Gerona, Lérida, Tortosa, Vic y Urgel, comunicándoles hallarse informado del perjuicio que sufren las "Comunidades y particulares pensionistas" del Real Patronato en la percepción de la cantidad que cada uno goza sobre los frutos y rentas de las mitras catalanas, por los descuentos que los prelados les hacen por gastos de administración, recolección de frutos, reducción de ellos a dinero, y benelicio y cobranza de las rentas de la mitra.

Enterado de este abuso seguido como práctica por unos y otros, que no debe ser disimulado ni permitida su continuación, el rey resuelve prevenirles para que paguen a los pensionistas íntegramente en dinero efectivo, en la capital del arzobispado, sin más demora que 18 meses para la primera paga y 6 meses para cada una de todas las siguientes, y sin otro descuento que el que por razón del subsidio y escusado corresponda a la cantidad de pensión asignada a cada uno como es justo, y lo deben hacer pues los gastos de administración, recolección de frutos, reducción de éstos a dincro, beneficio y cobranza de las rentas y todas las demás cargas que tienen las mitras, están descontadas y abonadas en la liquidación de valores que se hizo al tiempo de su ingreso en ellas.

Tras la fecha del real decreto abundan las cartas mandadas a los obispos recién electos para que paguen íntegramente las pensiones de designación real. En algunas ocasiones, el rey ruega a los obispos que paguen íntegramente las pensiones reales 
amparándose en que, sumándolas, no llegan al tercio del valor de la mitra ${ }^{30}$. En otras, a pesar de haber cargado la totalidad del tercio que por derecho le corresponde, el rey le "ruega" al obispo que pague íntegramente las pensiones, sin descontarles siquiera el subsidio y escusado 31 .

Las pensiones podían ser personales, a favor de un particular con carácter vitalicio; o institucionales, en beneficio de una institución, por lo general, un centro de estudios, un convento, un hospital, u otra institución de carácter benćfico o asistencial. Estas solían ser perpetuas, aunque algunas necesitaban ser renovadas cada 14 años. Las que aparecen con mayor frecuencia en la documentacion son las que recaen sobre el Hospital de la Corona de Aragón en Madrid ${ }^{32}$, y sobre la Universidad literaria de Cervera ${ }^{33}$. No obstante, otras instituciones también se vieron beneficiadas por las pensiones de designación real: la Capilla del embajador en La Haya ${ }^{34}$, el Convento de religiosas arrepentidas de Barcelona, el Colegio de la Compañía de Jesús de Lérida ${ }^{35}$, el Cabildo de la Catedral de esa misma población ${ }^{36}$, el Convento de religiosos dominicos de Vic ${ }^{37}$, y la Inquisición de Aragón ${ }^{38}$.

Por otro lado, Ios individuos beneficiados en las pensiones cclesiásticas configuran un amplio abanico sociológico. Entre cllos encontramos, eclesiásticos de diversa categoría ${ }^{39}$, alto personal de la administración ${ }^{40}$, parientes de obispos ${ }^{41}$, los mismos obispos ${ }^{42} \ldots$

Asimismo, la política de pensiones se nos revela ciertamente compleja. La preponderancia de pensiones personales nos permitiría hablar de una política de recompensas por los servicios prestados, en un momento en el que resulta crucial la creación de una red de fidelidades. No se trata, sin embargo, de una actitud meramente coyuntural, a causa de las consecuencias de la guerra ${ }^{43}$. Se inscribe dentro de una idea y un modelo de monarquía, con un fuerte componente dinástico-patrimonial, en la que cl monarca podía actuar sobre los bienes del Estado como si se tratasen de los suyos propios, en su condición de señor particular. Una idea que entró en crisis en estos momentos y que, a lo largo del siglo, fue derivando hacia una concepción estatal ista de la monarquía 44 .

Y terminaremos este apartado recordando que no sólo cargaba el rey pensiones sobre los frutos y rentas de las mitras. También lo podía hacer sobre las abadías de su Real Patronato ${ }^{45}$. En nuestro caso, las benedictinas claustrales de la Provincia Tarraconense Caesaraugustana.

Entre estas pensiones predominaban las individuales y vitalicias, beneficiando a clérigos de diferentes diócesis. El único caso de pensión institucional recayó sobre el Hospital de la Corona de Aragón en Madrid, siendo cargada sobre los frutos y rentas de la abadía del monasterio de Santa María de Ripol146.

Las cédulas de nombramiento de sus abades nos permiten conocer la riqueza de las abadías cargadas con pensiones reales. Si las ordenamos siguiendo un criterio descendente de recursos, obtendremos la siguiente lista: San Cugat del Vallés, San Pedro de Besalú, Santa María de Gerri, Santa María de Ripoll, San Salvador de Breda, San Pedro de Galligans, San Pedro de Camprodón, y San Esteban de Bañolas. 
Tras haber completado la relación de los derechos útiles que reportaba el Real Patronato a la monarquía, entraremos en el análisis de lo que Christian Hermann califica como derecho oneroso: la protección real de la Iglesia nacional ${ }^{47}$.

Los monarcas españoles, desde el Concilio de Trento, se consideraron protectores de la Iglesia nacional. Este sentimiento se acentuó con el advenimiento de la dinastía borbónica, en directa conexión con el auge de las posturas regalistas. De este modo, el espectro de competencias soberanas del rey penetró no sólo en las relaciones diplomáticas con la Santa Sede, sino en todas las expresiones de la vida de la Iglesia española, ordenada "bajo el poder civil"48.

Una de las principales manifestaciones de esa protección que los soberanos brindaban a la Iglesia nacional fue su intervención en determinados pleitos judiciales.

La mayor parte de dichas actuaciones tiene su origen en la defensa del Real Patronato y de las regalías de la Corona. En algunas ocasiones se trata de casos que van heredando los diversos monarcas. En este sentido, cabe destacar el relacionado con la provisión del priorato de la Iglesia Colegial de Santa María de Meyá que, iniciado en el reinado de Carlos II, aún no había hallado solución a finales del reinado de Carlos III, más de un siglo después ${ }^{49}$. En este tipo de pleitos, el rey aprovechará el Concordato de 1753 para proceder a la provisión de los beneficios de patronato cuestionado.

No obstante, no siempre triunfaban los intereses del rey. El ejemplo más claro de victoria legal de la otra parte es la que benefició a Bonifacio Ferrer el 21 de octubre de $1753^{50}$. Este fue provisto por Su Santidad en el beneficio de Santa María, fundado en la capilla del Castillo de Alós, sito en la diócesis de Urgel. Al pertenecer dicho beneficio al Real Patronato, según la opinión del fiscal de la Audiencia, se entabló en ésta pleito en primera instancia. La Cámara, al conocer la existencia de este expediente, en el que Ferrer pretendía la validación de su bula de nombramiento y de la toma de posesión del beneficio, actuó enérgicamente: los frutos de la prebenda fueron inmediatamente secuestrados, por decreto del 10 de abril de 1752 , y se suspendió la prosecución del pleito hasta nueva orden. Pero la apelación del afectado tuvo efectos poco frecuentes. Fernando VI, por decreto de 10 de octubre de 1753 , respetó la provisión pontificia ordenando el levantamiento del secuestro y la entrega de los frutos secuestrados a Bonifacio Ferrer, así como que no se le "embarazara" la posesión del beneficio. Y para su puntual cumplimiento escribió a las autoridades seculares de Cataluña. Asimismo, envió real despacho al obispo de Urgel para que dispusiera el cobro de los "sufragios y demás cargas" anexas al beneficio desde el momento del secuestro.

Otro grupo de documentos hace referencia a la exclusividad de la Audiencia del Principado a la hora de "sustanciar y determinar" los expedientes relacionados con el Patronato Real, en primera instancia, yendo las apelaciones dirigidas a la Cámara. La ley XVII, del título XVII, del libro I de la Novísima Recopilación, dada por Fernando VI en Buen Retiro por real decreto de 3 de octubre de 1748, y referente a las "reglas para el conocimiento de las causas del Real Patronato" aclara esta normativa: 
“(...) deseando dar oportuno remedio que asegure la más pronta administración de justicia, mando, que las Chancillerías y Audiencias respectivas conozcan y determinen en primera instancia, con las apelaciones á la Cámara, todas las causas y negocios en que, no dudándose de mi útil efectivo patronato, solo se controvierta sobre las dotaciones, rentas, derechos y preeminencias tocantes a las Iglesias y piezas de mi real presentación; á cuyo fin se darán por el Consejo de la Cámara las órdenes convenientes, con las de que cesen todos los Jueces subdelegados en estas particulares comisiones, y remitan lo pendiente en su asunto á los expresados tribunales (...)".

Estas órdenes reales en torno a la determinación de las causas del Real Patronato no fueron bien vistas por todos los pleiteantes. Si bien la designación de la Audiencia como tribunal competente era aceptada de modo generalizado, los fuertes desembolsos necesarios para poder sobrellevar las apelaciones en la Cámara podían alejar de los juicios a las partes insatisfechas tras las sentencias en primera instancia.

El caso más sangrante es el de los domeros y comunidad de presbíteros de la Iglesia de San Pedro de la villa de Ripoll51 ${ }^{5}$. Estos se enfrentaban al abad del monasterio de Santa María de Ripoll porque éste admitía libremente en dicha iglesia a presbíteros no naturales de la mencionada villa. Tras no quedar de acuerdo con la sentencia de la Audiencia de Barcelona, apelaron a la Cámara. Esta requirió al referido tribunal del Principado el envío de los autos del pleito. Así se procedió. Pero los domeros protestaron por creer viciados y sospechosos los instrumentos remitidos, por lo que demandaron que se enviaran de nuevo los autos. Carlos III accedió a la petición, por lo que, por real despacho de 14 de agosto de 1763, ordenó a la Audiencia que los enviaran, pero corriendo las costas a cargo de los apelantes. No habiendo aún recibido la Cámara dichos autos a inicios de 1766, el rey, en virtud del decreto de 26 de febrero de esc año, expidió real cédula fechada el 6 de marzo para que las autoridades competentes hicicran saber a los domeros y presbíterios de la comunidad de la Parroquial de San Pedro que si dos meses después de hecha la notificación no hacían presentes dichos instrumentos en la Cámara, la apelación se declararía desierta. Los domeros informaron a la Cámara que por ser tan costosa la compulsa y el transporte -"que debe realizarlo uno de los porteros bien asalariados"- de autos tan voluminosos, y por los crecidos gastos seguidos de la instancia de apelación, se veían obligados tristemente a abandonar su derecho a apelar, pese a los gravísimos perjuicios derivados de la sentencia, a menos que "la bondad real" no diese comisión a la Audiencia para el conocimiento de dicha apelación durante el año y medio siguientes, período en el que se mantendría al abad en tan "penosa" facultad de admitir en su comunidad a presbíteros no naturales de la villa de Ripoll. Tras ser escuchados por la Cámara, con los antecedentes del asunto y lo expuesto por el fiscal, y habiendo cumplido el término señalado para la remisión de los autos, por decreto del primero de noviembre de 1766, se declaró desierta la apelación, pasando "cn autoridad de cosa juzgada el auto definitivo de la Audiencia de 12 de agosto de 1762". Y para informar de la resolución a ambas partes se expidieron sendas reales cédulas con fecha de 20 de noviembre de 1766. 
También era competencia del monarca -como patrón de la Iglesia nacional- el determinar en las causas que afectaban al patronato de particulares. Destacaremos dentro de este grupo un caso que resulta especialmente interesante, pues en él juega un papel importante la Santa Sede. En pocas palabras, podría decirse que Carlos III da consistencia al blindaje del patronato de un beneficio que podría en cualquier momento enredarse en la tela de araña de las reservas pontificias.

Tras el fallecimiento de Domingo Planas, al quedar vacante el beneficio de Santa Cruz en la Iglesia Colegial de San Feliu de Gerona, se abrió este pleito en la Cámara con la intención de declarar a quién tocaba legítimamente el derecho de presentación. El abad y cabildo de la Colegial demostraron al rey con varios documentos que el beneficio era de patronato de legos, y que en esta calidad les dejó la presentación su fundador, "con tan varias y estrechas condiciones" que si, en algún momento pretendía proveerlo Su Santidad o el nuncio, "desde luego, se les estaba privando del patronato". Por ello, le suplicaron que lo declarara libre de las reservas pontificias, de modo que no pudiera proceder la Santa Sede a su provisión aunque las vacantes se produjesen en los meses apostólicos "que corresponden por el concordato"; y que expidiera el despacho correspondiente para poder poner en posesión del beneficio al nombrado "por el canónigo turnario o según práctica o como la merced real fuese".

Visto en la Cámara, con lo expuesto por el fiscal, y reconociendo que, aunque el patronato de dicho beneficio era "eclesiástico como dejado a persona y comunidad eclesiástica, se hallaba, sin embargo, enteramente libre y ejemplo de toda reservación apostólica y de la disposición del último concordato", tanto porque las cláusulas de la fundación eran absolutamente incompatibles con la disposición de las reservas ${ }^{52}$, como porque fue voluntad expresa del fundador excluir todo lo que pudiere impedir al abad y cabildo la presentación en todo tiempo y vacante, el rey declaró, por resolución a consulta de la Cámara de 21 de julio de 1762, que el mencionado beneficio estuviera exento de las reservas y de la disposición del último Concordato y que, en su consecuencia, pudiera entrar en posesión el provisto por el canónigo turnario, y en su conformidad rogó y encargó, mediante real cédula del 5 de septiembre de $1762^{53}$, al obispo de Gerona, a su provisor y vicario general, y a las demás personas a quienes tocar pudiere, lo tuvieran así entendido para su cumplimicnto. Y que registrada esta real cédula en los libros de la Curia Episcopal de Gerona, se devolviera el original a la parte de la Colegiata de San Feliu para su observancia, y para que la tuviera en guarda de su derecho ${ }^{54}$.

Por tanto, como hemos podido comprobar, era competencia real defender los derechos de patronato de sus súbditos frente a las posibles intromisiones de la Santa Sede.

Para poder llevar a cabo estas intromisiones, el papa se servía de variados artificios o instrumentos, entre los que destacan las bulas, breves y rescriptos apostólicos, expedidos por la Curia pontificia. Habitualmente, cuando éstos intentaban inmiscuirse en sus derechos y regalías, la Corona procedía a su recogida, envío y retención en la Cámara, con el consiguiente secuestro de las rentas del beneficio al que fueran dirigidos, hasta el momento de la sentencia definitiva del juicio. 
Otro grupo de intervenciones reales en pleitos es el que hace referencia a cuestiones monetarias o, en general, al cobro indebido de rentas de cualquier tipo, tanto en moneda como en especie. Como ya se indicó, la ley dada por Fernando VI el 3 de octubre de 1748 llevaba a la Audiencia del Principado todas las causas y negocios tocantes a las Iglesias del Real Patronato en las que se disputaran dotaciones y rentas, y a la Cámara sus apelaciones ${ }^{55}$. Esta disposición real se plasmó en el cuerpo general de leyes, entre otros motivos, por la existencia los años inmediatamente anteriores (entre 1739 y 1746) de un aluvión de pleitos de este tipo. Tres fueron los focos principales: la abadía del monasterio de Santa María de Ripoll, la villa de Cambrils, y, sobre todo, el arciprestazgo de la Iglesia Colegial de Santa María de la villa de Villabeltrán.

También participó la Corona, a modo de árbitro, en los pleitos dirimidos por los obispos, por creer disminuidos sus privilegios, facultades y jurisdicciones. Destacan los intentos vanos del obispo de Urgel por menoscabar la "omnímoda jurisdicción ordinaria", esto es, la jurisdicción casi episcopal, que ejercía en su "territorio separado" el arcipreste de la Colegial de San Pedro de Ager. O los inútiles enfrentamientos de Asencio Sales, obispo de Barcelona, contra diversos abades de la Congregación Benedictina Claustral sobre puntos de jurisdicción episcopal, pues éstos gozaron, por su pertenencia al Real Patronato, de un trato de favor. Es raro encontrar un pleito en el que no salgan victoriosos y con sus facultades confirmadas, si no ampliadas.

Y en último lugar, los monarcas eran, asimismo, los encargados de realizar las designaciones de árbitros legales en las causas con conflictos de competencias, y de instigar a las partes enfrentadas a la transacción de concordias.

Dejando aparte la intervención en pleitos judiciales, la protección real de la Iglesia nacional se manifestó, además, en una amplia gama de actuaciones.

Comenzaremos dando reseña de dos casos en los que los monarcas hubieron de intervenir inmediatamente para coartar una serie de abusos que se estaban cometicndo en perjuicio de particulares y comunidades eclesiásticas.

En el primero de ellos, la corona defendió en 1757 a Benito Jaime de Romeo y Ccrezo, que había sido nombrado despensero mayor del monasterio de Santa María de Ripoll, pues el abad le impidía la toma de posesión del oficio ${ }^{56}$.

En el segundo, en 1773, Carlos III benefició al monasterio de Santa María de Labaix, al confirmar la unión del priorato de San Ginés -en virtud de un indulto de Benedicto XIV-, para que no volviera a darse en encomienda a clérigos seculares, por la desatención de éstos a las obligaciones espirituales. En este documento, Carlos III nos muestra una verdadera declaración de principios relativos a su regalía de patronato de la Iglesia española, pues afirma que le corresponden "la protección de los Sagrados Cánones y Establecimientos eclesiásticos y su debida y cxacta observancia, y el cortar los abusos que se produzcan contra ellos, conservando a mis vasallos en la quicta y pacífica posesión de sus privilegios y exenciones" 57.

Con la Guerra de Sucesión, y las rupturas temporales de las relaciones con Roma, la monarquía consiguió dos importantes logros. Por un lado, frenó la cvasión de capitales hacia Roma, con el control -mediante secuestros- de las rentas de vacan- 
tes y espolios. Y por otro, proveyó a sujetos adictos y leales en algunas de las piezas eclesiásticas de más lustre del Principado.

A lo largo del período estudiado, fueron numerosas las ocasiones en que los monarcas españoles intentaron extender su Real Patronato. Para ello encargaron inspecciones e investigaciones de todo tipo, y en los distintos archivos del reino, en aras de averiguar la fundación, dotación y presentaciones de diversos beneficios ${ }^{58}$.

Con mayor urgencia, si cabe, intervino la Corona cuando sintió atacada dicha regalía por la Santa Sede. De este modo, Fernando VI, el 16 de diciembre de 1749 escribió al cardenal Portocarrero para advertirle que estaba informado de que la Dataría iba a proveer distintas piezas eclesiásticas en perjuicio de los reales derechos. Deseando evitarlo, le encargó que, antes de dar curso a las provisiones practicadas por dicho organismo pontificio que recayeran sobre beneficios que constasen tocar al Real Patronato o, al menos, se dudase que le pudieran pertenecer, procediera a dar noticia de ello a la Cámara, para que allí se determinase lo más justo y conveniente a la preservación de la regalía. Y con el mismo texto y fecha, expidió reales cédulas dirigidas al metropolitano de Tarragona, a los demás obispos del Principado y a los cabildos de esas catedrales, y a los abades de los monasterios benedictinos claustrales en Cataluña ${ }^{59}$.

Carlos III dio un nuevo enfoque, mucho más ambicioso, a las pretensiones reales de extender la regalía del Real Patronato. Sus esfuerzos se orientaron hacia la declaración papal de los monasterios cistercienses de Aragón, Valencia y Cataluña como pertenecientes al Patronato Real.

Cuidar por la dignidad del culto, y mantener a las comunidades e iglesias españolas con el honor y lustre que merecían, eran otras competencias que los monarcas se arrogaban en su calidad de patrones de la Iglesia nacional.

Aunque en el ámbito rural la observancia de los preceptos de la Iglesia era virtualmente universal, en las ciudades comenzaron a existir tenues signos de falta de afecto hacia la Iglesia. Estos se tradujeron en la aparición de otro mundo de devoción que subrayaba lo individual y sus relaciones con Dios, y en la decadencia progresiva de las asociaciones pías o cofradías ${ }^{60}$. A esa caída contribuyeron las campañas desencadenadas por el Consejo de Castilla para reducir, o cuando menos, acceder al control de las cofradías, únicas entidades en el Antiguo Régimen con ciertos -y peligrosos- derechos de asociación, y a las que, con frecuencia, se hacía responsables de tantos males 61 .

A pesar de la hostilidad manifiesta de las tendencias regalistas hacia las cofradías, en 1725, Felipe V honró a una de ellas, la de Nuestra Señora de la Cinta de Tortosa ${ }^{62}$, aceptando escribir su real nombre en el Libro de los Hijos de María Santísima de la Cinta de su Hermandad, en calidad de Hermano mayor ${ }^{63}$. Del mismo modo procedió su hijo Carlos III en 1768 , cuando el prior y mayordomos de la relerida hermandad le elevaron una súplica similar para que igualmente condescendiera a que se "sentase" su real nombre en el Libro de dicha cofradía con el mismo título de Hermano mayor 64 . 
Los monarcas debían, asimismo, pedir al papa la extensión de cultos, o la canonización de beatos, en atención de las súplicas de sus súbditos. Conocemos la extensión de diversos rezos: un rezo doble para San Fructuoso de Tarragona y sus diáconos, Augurio y San Eulogio (1726) ${ }^{65}$; un rezo especial en honor de la mencionada Virgen de la Cinta de Tortosa $(1727)^{66}$; un rezo con rito doble en honor de San Ermengol, patrón de la diócesis de Urgel (1732) ${ }^{67}$; otro para San Indalecio (1739)68; y por último, la extensión del culto de Nuestra Señora de la Purísima Concepción $(1758)^{69}$. En cuanto a la petición de canonización de beatos, sólo hemos hallado un caso en la documentación: el de Dalmacio Moner, a petición del cabildo catedralicio y la ciudad de Gerona en $1717^{70}$.

Otra actividad del rey en su patronazgo de la Iglesia nacional era admitir bajo su protección a diversas congregaciones ${ }^{71}$. Caso prototípico es el de la Congregación del Corazón de Jesús y Concepción de María fundada en la ciudad de Manresa pues, por decreto de 25 de octubre de 1744, Felipe V le otorgó su protección, "con el fin de que se conserve con este distinguido honor", enviando despacho al Capitán General el 8 de diciembre siguiente para que así lo tuviera entendido ${ }^{72}$.

Un documento fechado el 23 de enero de 1772 nos puede servir para comprobar hasta qué límites llegaba la influencia real en cuestiones eclesiásticas ${ }^{73}$.

Hace referencia a la reglamentación real del boato y la dignidad del culto. En él, Carlos III se vio obligado a intervenir para poner fin a las disputas entre Joaquín Antonio Sánchez Ferragudo -obispo de Lérida- y José Antonio Senronia -canónigo y diputado del cabildo catedralicio de esa ciudad y obispado- sobre las sillas que el primero debía ocupar en el coro para asistir a los oficios divinos.

En observancia, protección y cumplimiento de lo dispuesto por el Concilio de Trento, mandó que el obispo de Lérida se sentara en dos sillas exclusivas que debían tener "la distinción y el adorno" correspondientes a su dignidad, tanto para tomar posesión de la mitra como para su residencia: una junto a la reja, y la otra entre las dos alas del coro.

Además de contribuir al lustre y el honor de las iglesias de sus reinos, también buscaba el rey con sus intervenciones el bien común de la comunidad eclesiástica. Ambas intenciones las hallamos explícitas al decretar Felipe $V$ la creación en el Principado de las tres canonjías de oficio que no existían en sus catedrales, esto es, la magistral, la doctoral, y la lectoral ${ }^{74}$.

El ejemplo más claro de esa preocupación real por el bien de sus súbditos cclesiásticos es su actuación ante las convocatorias de capítulos de las órdenes regulares.

A mediados del siglo XVIII, si exceptuamos a un grupo reducido de religiones (la de San Benito, la de San Bernardo, la Premonstratense, la de San Jerónimo, la de San Francisco, la del Carmen Descalzo, la Trinidad Descalza, la Merced Descalza, y la Merced Calzada) ${ }^{75}$, el grueso de los conventos españoles seguía formando parte de congregaciones más amplias, que excedían el ámbito territorial de la monarquía hispana. Por ello, cran frecuentes las salidas de España de sus cabczas de religión para acudir a los capílulos generales. 
En 1743, el vicario general de los carmelitas descalzos informó a Felipe V sobre la proximidad del capítulo general de esa religión, que debía celebrarse en Roma en junio del año siguiente. Atendiendo a las dificultades causadas por la guerra de sucesión austríaca y los riesgos que suponía el viaje tanto por tierra -por haberse abierto un nuevo frente bélico en Italia ${ }^{76}$ - como por mar -por la presencia naval inglesa en el Mediterráneo-, el rey encargó al citado vicario, por real despacho del 12 de noviembre, que comunicara a todos los conventos de su jurisdicción que les estaba terminantemente prohibida la salida de España ${ }^{77}$.

La voluntad de control de las órdenes religiosas del país no se limitaba tan solo a la censura de las comunicaciones con el exterior. También se hizo patente mediante la inspección y vigilancia efectiva de las disposiciones internas de los capítulos territoriales y el control de la vida monástica.

Esto lo podemos comprobar años después cuando, el 11 de abril de 1754, Fernando VI escribía a Bartolomé Sarmentero, obispo de Vic, para designarle -conforme a la voluntad del nuncio apostólico- presidente del capítulo provincial de los trinitarios calzados, que tendría lugar en Barcelona, con la intención de evitar la inquietud y parcialidad de los religiosos de esta orden en la provincia de Aragón, Cataluña y Valencia, a la hora de realizar las designaciones y nombramientos de los oficios y demás cargos, y para que recaigan "en las personas de más aprobación y prendas, sin que se atienda a otros fines", siendo todo "para el mayor servicio de Dios". Por lo tanto, el rey interviene para coartar los corruptos abusos que se estaban cometiendo, y en beneficio del buen funcionamiento y la observancia de las reglas de esa religión ${ }^{78}$.

La apuntada atención que la monarquía prestó en pos del correcto funcionamiento interior de la Iglesia nacional tuvo múltiples manifestaciones. En 1723 , Felipe V procedió a la copia y envío de los estatutos del Colegio de Santiago y San Matías de Tortosa, necesarios para su buen funcionamiento, pues con las turbaciones de la guerra se habían perdido ${ }^{79}$.

Por otra parte, cuando el rey decidía nombrar a algún miembro del estado eclesiástico para una plaza judicial secular, se veía en la obligación de evitar "la nota de irregularidad" encargando a su representante en Roma que suplicara a Su Santidad el despacho de la dispensa necesaria para que "pudiera vestir toga y votar en todas las causas criminales sin restricción alguna". Esta competencia real aparece reflejada en un documento de 1758 en el que el rey escribe al cardenal Portocarrero para que suplique al papa la expedición de la mencionada dispensa con el fin de que Antonio Villalba, clérigo de prima tonsura, pudiera obtener una plaza de ministro de la sala del crimen en la Audiencia de Cataluña, gozando de una pensión de 50 ducados y 6 julios de moneda de la Cámara Apostólica, cargada sobre los frutos y rentas de la abadía de San Esteban de Bañolas ${ }^{80}$.

Otra atribución real consistía en designar, junto con el nuncio de Su Santidad, a Ios visitadores de monasterios del Real Patronato, que tenían la misión de revisar sus estatutos a fin de realizar los cambios convenientes para $\mathrm{el}$ buen funcionamicnto interno de las comunidades y el mantenimiento de la observancia de los preceptos de 
la regla monástica correspondiente. En atención a una súplica del monasterio de Bellpuig de las Avellanas, en 1725, Felipe V designó como visitador a Baltasar Sayol, abad de Poblet, con la misión de revisar sus estatutos de gobierno y establecer las nuevas ordenaciones conducentes "al mayor servicio de Dios, utilidad y beneficio de dicho monasterio y sus individuos", remitiéndolas a la Cámara ${ }^{81}$.

Fueron numerosas las intervenciones reales en materias jurisdiccionales. Normalmente, los monasterios se quejaron de la intromisión de los oficiales reales en sus privilegios y derechos de jurisdicción temporal, pues la Intendencia procedió en repetidas ocasiones al nombramiento de bailes criminales en diversas baronías pertenecientes a dichas abadías.

La última manifestación real que mencionaremos, en relación con el mantenimiento del orden eclesiástico, es la referente a la concesión de licencias reales para los contratos enfitéuticos de las tierras propias de los monasterios del Real Patronato. En 1773, Carlos III concedió tales licencias a dos monasterios benedictinos claustrales, el de San Pedro de Galligans ${ }^{82}$, y el de San Esteban de Bañolas ${ }^{83}$, amparándose en los provechosos fïnes que de las enajenaciones se seguían: plantío de viñas para con los frutos y rentas derivados proceder a la redención de los censos cargados sobre la villa de Galligans; y fábrica de casas para la extensión de la población y la feligresía.

También correspondía al rey velar para que las necesidades espirituales de sus súbditos estuvieran bien cubiertas. Un medio para conseguir este utópico fin fue la crección de capillas en lugares despoblados. Un ejemplo de ello lo tenemos en la resolución de Carlos III en 1774 de erigir una capilla en el sitio despoblado de las Salinas, Ilamado de los Alfaques -en la diócesis de Tortosa-, a fin de que "el crecido número de sus dependientes consigan el pasto espiritual que necesitan"84.

Es sabido que el catolicismo personal de Carlos III no era la religión de gran ceremonial y prácticas supersticiosas tan extendida en la España del XVIII ${ }^{85}$. Más bien, el Estado, de acuerdo con sus ideales ilustrados, pretendía reformar la Iglesia, eliminando la superstición, racionalizando su administración, c incrementando el nivel intelectual general de la clerecía (para crear una Iglesia más atenta a sus responsabilidades pastorales) ${ }^{86}$.

En 1766, Carlos III promulgó un decreto con el fin de estimular la fundación a gran escala de seminarios e incrementar el nivel de instrucción de los ya establecidos ${ }^{87}$. Perseguía con ello varios objetivos. Por un lado, convertirlos en para-universidades, liberándolos del control de los cabildos catedralicios y eliminando las disputas entre escuelas filosóficas. Por otro, poner fin a la formación de sacerdotes en las escuelas de latinidad locales, donde los candidatos al sacerdocio recibían una educación tan rudimentaria que apenas iba más allá del catecismo y de la forma de decir misa y de administrar los sacramentos.

Los esfuerzos de Carlos por incrementar el número de seminarios fueron tan fructíferos que se fundaron 17 durante su reinado. Pero las reformas que promovió el Estado fracasaron a la hora de incrementar significativamente el nivel educativo del 
clero más bajo; la mayoría continuó adquiriendo los conocimientos que necesitaban para su ministerio de la manera tradicional, y los seminarios tampoco fueron capaces de igualar el prestigio de las facultades universitarias de teología y fïlosofía.

La expulsión de los jesuitas de España en 1767 abrió nuevos horizontes al gobierno reformista de Carlos III. Callahan opina que el motivo de la expulsión no tuvo un carácter antirreligioso. La Corona ordenó que las casas y rentas de la orden fueran destinadas a fines religiosos y educativos. La confiscación de las propiedades de los jesuitas permitió al Estado establecer nuevas escuelas bajo auspicios religiosos, pero con planes de estudios más avanzados, crear instituciones de caridad bajo dirección clerical, y fundar nuevos seminarios para mejorar el nivel del clero parroquial ${ }^{88}$.

A estas directrices responde la decisión de Carlos III en 1772, tras la consulta de la Cámara, de utilizar el edificio y la iglesia que tenían los jesuitas en Tortosa para el establecimiento de un seminario sacerdotal ${ }^{89}$.

No es el único caso de erección de seminarios en Cataluña. Dos años después, el obispo Bernardo Velarde representó al rey "la gran utilidad de erigir un seminario conciliar" en el Real Colegio de Santiago y San Matías de la ciudad de Tortosa, ya que al ser su patrón por haber sido fundado por Carlos I, necesitaba su real consentimiento ${ }^{90}$.

Otro tipo de contribución eclesiástica a la cultura fue la construcción y conservación de archivos y bibliotecas, efectuadas unas veces por mandato de los propios obispos, otras por iniciativa de los curas párrocos o de las propias congregaciones regulares, como es nuestro caso. En 1771, Manuel Abad y Lasierra recibió del rey comisión para reconocer los archivos y bibliotecas de los monasterios de su congregación, la Benedictina Claustral Tarraconense Caesaragustana91.

Otra disposición posterior, dada por Carlos III, confïrma esta línea de actuaciones. Se trata del despacho de 26 de mayo de 1774 dirigido al doctor Antonio Rubiol para que se hiciera cargo de la biblioteca de la diócesis de Lérida"2.

Asimismo, con el avance del siglo XVIII, la monarquía fue ocupándose de una función que con anterioridad era patrimonio casi exclusivo de las instituciones eclesiásticas: la asistencia a los marginados. En 1751, Fernando VI admitió bajo su protección y aprobó las constituciones de una reciente fundación: el Monte de Piedad de Nuestra Señora de la Esperanza y Salvación de las Almas, de Barcelona, que tenía dos objetivos fundamentales: por un lado, extinguir los abusos usurarios que se extendían profusamente por la ciudad; y por otro, el recogimiento de las mujeres públicas en una Casa de Retiro ${ }^{93}$.

La Iglesia era una institución rica y poderosa, y en una nación donde la práctica religiosa estaba tan profundamente arraigada, imponía sus modelos de conducta sobre toda la sociedad. Puede afirmarse que la verdadera fuerza de la Iglesia residía en su ascendente espiritual sobre la población, desde la aristocracia hasta las masas campesinas. Sobre éstas ejercía una influencia casi mágica, una influencia que parecía impregnar todos los aspectos de la vida. Los momentos más básicos de la exis- 
tencia humana -nacimiento, matrimonio, muerte- estaban rodeados de un rilual sacramental. Las procesiones religiosas llenaban las calles en las grandes festividades del año. Tanto los campesinos como los habitantes de las ciudades establecían sus horarios diarios al toque de las campanas de sus iglesias ${ }^{94}$.

La Iglesia controlaba completamente el tiempo, incluso el dedicado al ocio, pues establecía más de noventa fiestas de guardar, en las que no se trabajaba, amén -nunca mejor dicho- de la costumbre inveterada de guardar los lunes.

Y en el siglo XVIII, la monarquía no ocultaba su intención de intervenir, de romper tan arraigado monopolio de la Iglesia, de tener algún control -aunque fuera mínimo- del tiempo cotidiano.

En el Concilio episcopal de la Provincia Tarraconense celebrado en 1727, se trató el tema de la enmienda y reforma de algunos abusos introducidos contra la observancia de diferentes preceptos, especialmente el quebrantamiento de los sagrados días de fiesta por trabajar en ellos, a pesar del grave daño que tal proceder suponía para la conciencia de los católicos infractores.

Esta falta tenía su origen en la necesidad que tenían "rústicos, labradores y artesanos" de trabajar para poder escapar de la miseria, "dada la esterilidad del país", propia del período postbélico ${ }^{95}$. Se quejaban de los excesivos días de precepto que mandaba guardar la Iglesia ${ }^{96}$.

El Concilió decidió elevar al papa una súplica con el objeto de que se dignara permitir a los moradores del Principado trabajar en algunas de estas fechas preceptivas, quedando en "total observancia de precepto riguroso las 52 dominicas del año, los días de la Natividad del Señor, y siguiente de San Esteban, el de la Circuncisión, Epifanía, el día siguiente al de la Resurrección, Ascensión del Señor, día siguiente al de Pentecostés, día de Corpus, días de San Juan Baptista, San Pedro y San Pablo, Santiago -patrón de España-, y día de todos los Santos, con las cinco festividades de María Santísima, Madre de Dios". En los restantes días preceptivos, cumplida la obligación de oír misa, se podría trabajar, con la conciencia tranquila.

Asimismo, cl Concilio pidió a Felipe $\mathrm{V}$ que interpusiera su influencia ante Su Beatitud para lograr la consecución del mencionado indulto.

El monarca no dudó en despachar una real cédula el 12 de marzo de 1728 al cardenal Bentivoglio condescendiendo con la petición de los obispos del Principado.

Resulta curioso observar que la concepción del trabajo del pueblo catalán muestra gran afinidad con las ideas que sobre el tema tendrían posteriormente los representantes de la denominada "Ilustración oficial". Estos declararon abiertamente la guerra a la costumbre de guardar los lunes y a los excesivos días de precepto, incompatibles con su aversión al ocio. ${ }^{97}$ Los ilustrados consideraban que el ocio y la fiesta -referencia de la percepción del tiempo en la religiosidad popular- se habían multiplicado en desmesura y a costa del trabajo. Entre ellos, Campomanes se convirtió en adalid del combate contra tantos días inútiles. Tanto él como los otros debeladores de las fiestas hablaban del peligro que suponían para el orden público; para 
el jornalero, que al no poder trabajar, se veía, junto con su familia, al borde de la miseria; de la necesidad de romper con la costumbre inveterada de "guardar los lunes" y de trasladar los festivos a los domingos ${ }^{98}$.

La monarquía, como ente conservador de un status definido por una tradición plurisecular, consideraba como una obligación propia el mantenimiento de los privilegios adquiridos por las diversas comunidades e instituciones eclesiásticas. No faltan en la documentación casos en los que los diversos obispos y abades del Principado ${ }^{99}$ demandan a la corona la confirmación de sus inveterados e indiscutibles privilegios, para que no se les embarace en su posesión y disfrute.

Como ya se apuntó en el espacio dedicado a las pensiones, a las diferencias en las dimensiones territoriales de las diócesis, correspondían severas disparidades de renta. Por ello, la monarquía era consciente de la necesidad de realizar una racionalización del mapa eclesiástico ${ }^{100}$. No obstante, las dificultades para vencer los intereses adquiridos impidieron cualquier modificación sustancial de las demarcaciones territoriales de las diócesis. Durante el siglo XVIII se establecieron cuatro nuevas sedes -Santander, Tudela, Ibiza y Menorca-, pero sólo la primera estaba localizada en una ciudad importante.

En Cataluña, durante 1720, Felipe V mostró su intención de trasladar la sede de Solsona a la ciudad de Cervera, donde acababa de establecer la Universidad literaria, por lo que escribió a su representante en Roma, el cardenal Aquaviva, para que elcvara su súplica al Sumo Pontífice. Pero pese a las esforzados trabajos del cardenal y a las explícitas justificaciones del monarca, su intención no se tradujo en ningún cambio en el mapa eclesiástico de la Provincia Tarraconense ${ }^{101}$.

Y para acabar con esta exposición sobre las facultades y competencias de los reyes españoles como patrones de la Iglesia nacional, hablaremos de la atención que prestaron a los asuntos de vinculaciones económicas.

Por un lado, cuando se trataba de asegurar el sustento a comunidades eclesiáslicas que estaban bajo su Real Patronato. Esta es la situación en que se vio inmerso en 1722 el monasterio de Nuestra Señora de Montserrat cuando la corte romana se negó a rcnovarle una indulgencia, sobre la venta de unas medallas y cruces que fabricaban sus ermitaños. Felipe $\mathrm{V}$ pidió al papa en dos ocasiones la confirmación de la gracia; primero ese mismo año, y después, en 1725. No conocemos si tuvo ćxito o no. Pero lo que queda muy claro es que no dudó el rey en actuar en atención a las necesidades del citado monasterio ${ }^{102}$.

Y por otro lado, a la hora de intentar racionalizar la organización y dotación de benclicios del Real Patronato.

En los fondos encontramos varios documentos de este tipo. Entre 1766 y 1767 , el rey reorganizó las rentas de las canonjías y dignidades de la Catedral de Tarragona, mostrando su intención de "mudar el estado de esa Iglesia Catedral en la parte que baste para el socorro de sus necesidades y para el mayor esplendor del Culto divino" 103 .

Entre 1767 y 1769 , suprimió dos de las tres monjías o mensalías de la 
Parroquial de San Martín de la villa de Arén, destinando su producto a las arcas del monasterio de Santa María de Labaix ${ }^{104}$.

En 1770, Carlos III aprobó las uniones y supresiones de beneficios incongruos del arciprestazgo de la Iglesia Colegial de San Pedro de Ager ${ }^{105}$. Y tres años más tarde, el monarca hizo lo propio con el Plan general de beneficios del priorato de Santa María de Meyái ${ }^{106}$.

También de 1773 es el último documento que incluiremos en la investigación. Se trata de la formalización del decreto respectivo a la residencia e incompatibilidad de las dignidades y canonjías de esa Catedral de Tortosa ${ }^{107}$.

Todas estas labores ocuparon a los reyes españoles. No obstante, los logros obtenidos no alcanzaron las proporciones deseadas. $Y$ aunque se avanzó en determinados campos, la geografía eclesiástica catalana encaró el último cuarto de siglo con una salud que iría decreciendo hasta el tratamiento de choque que devendría con el período de las desamortizaciones.

\section{NOTAS}

1.- Antes de realizar cualquier análisis sobre la Historia de la Iglesia en España durante el siglo XVIII, es necesario citar una serie de textos indispensables. En primer lugar, la gran obra de R. OLAECHEA: Las relaciones hispano-ronanas en la segunda mitad del siglo XVIII. Zaragoza. 1985. También revisten especial interés otros libros. R. GARCíAVILLOSLADA (coord.): Historia de la Iglesia en España, vol. IV, B.A.C., Madrid, 1979. J. PRADELLS-E. LA PARRA (edits.): Iglesia, sociedad y Estado en España, Francia e Italia (ss. XVIII al XX), Alicante, 1992. Q. ALDEA VAQUERO Y OTROS: Diccionario de Historia eclesiástica, Madrid, 1973. Y finalmente, W. CALLAHAN: Iglesia, poder y sociedad en España. 1750-1874, Madrid, 1980.

2.- Dichos fondos han sido catalogados por $\mathrm{M}^{a} \mathrm{~J}$. ÁLVAREZ-COCA GONZÁlEZ: "La Corona de Aragón: documentación en el Consejo y la Cámara de Castilla (1707-1834). Fuentes en el Archivo Histórico Nacional", en Hispania, 173 (1989), pp. 895-948.

3.- A. DOMínGUEZ ORTIZ: "Aspectos sociales de la vida eclesiástica" en R. GarcíaVilloslada (dir.): Historia de la Iglesia en España, B.A.C., Madrid, 1979, vol. IV, p. 70.

4.- Tales prebendas fueron cinco: En la diócesis de Barcelona, el bencficio simple de la Parroquial del lugar de Villamor (A. H. N. "Registros del Real Patronato". Libro 280, ff. 14v-15v.), y el beneficio de San Salvador y Santa Magdalena en la Parroquial de San Estcban de la villa de Granollers (A. H. N. "Registros del Real Patronato". Libro 280, ff. 33v-35). En la de Gerona, el beneficio de San Julián y Santa Basilisa de la Parroquial de Llers (A. H. N. "Registros del Real Patronato". Libro 280, f. 104v), y el beneficio de San Francisco del convento de Santa María de Belloch (A. H. N. "Registros del Real Patronato". Libro 280, f. $11 \mathrm{lv}$ ). Y en la Catedral de Urgel, el beneficio de San Simón y Judas (A. H. N. "Registros del Real Patronato". Libro 280, ff. 42-43). 
5.- Novísima Recopilación, libro I, título XVIII, ley III: "El Consejo de la Cámara por circular de 8 de Noviembre de 1753 , aprobada por S. M. en resolución a consulta de 18 de junio de 1753. Requisitos para la provisión de Beneficios simples pertenecientes á donatarios de la Corona ó á presentación real. Para todos los Beneficios simples, de qualquiera calidad que sean, que pertenezcan á algun donatario por Reales donaciones, y vacaren en los quatro meses ordinarios, ú otros en que tuviere actualmente el dicho donatario la posesion de presentar, remita por mano del Secretario de la Cámara la nominacion que hiciere de un sugeto para cada Beneficio, á fin de que recaiga sobre esta nominacion la Real aprobacion. Y quando en algun territorio exênto vacare á presentacion Real en virtud del Concordato algún Beneficio simple ó Préstamo, se dará cuenta por mano del Secretario, con expresion de su valor y circunstancias, para que S. M. use de su Real derecho".

Cuatro fueron los beneficios de donatarios de la Corona, que requirieron la confirmación real, todos ellos sitos en los monasterios benedictinos claustrales de la diócesis de Gerona: En Santa María de Amer y Rosas, un beneficio simple porcionero (A. H. N. "Registros del Real Patronato". Libro 281, ff. 317-318v). En San Esteban de Bañolas, la reviscolería (A. H. N. "Registros del Real Patronato". Libro 281, ff. 364-365v), y el beneficio de San Miguel en el altar de San Miguel (A. H. N. "Registros del Real Patronato". Libro 281, ff. 389v-391). Y, por último, el beneficio simple de Santa María de la Parroquial del lugar de San Lorenzo de Sous, llamado comúnmente San Lorenzo del Monte, perteneciente al monasterio de San Pedro de Besalú (A. H. N. "Registros del Real Patronato". Libro 281, If. 323-324).

6.- R. Olaechea, op. cit., p. 170.

7.- En la distribución de beneficios, la Cámara intentaba no alejarse mucho de dos principios generales. Por un lado, proveer las vacantes con la mayor brevedad -hecho que muy poco frecuentemente se conseguía-. Y por otro, elegir a los pretendientes más dignos y apropiados para el servicio y utilidad de las piezas eclesiásticas.

8.- Aunque la influencia del Padre Confesor queda plenamente demostrada en la multitud de consultas y documentos en que su nombre aparece expresamente, en la documentación manejada, el Confesor Real no aparece en ninguna ocasión. La razón de ello hay que buscarla en el hecho de que la influencia del Padre Confesor se hace manifiesta en el preciso momento de la elección del clérigo para un beneficio determinado, y no después, cuando se remite la real cédula a Roma con el fin de obtener las bulas o gracias correspondientes, necesarias para la confirmación de la resolución real.

9.- Capilla del Castillo de Fornells. Beneficio de Nuestra Señora Antigua de la Parroquial de Pals. Beneficio de San Quintín de la Parroquial de la villa de Ripoll. Y tres beneficios en la villa de Torroella de Montgrí: beneficio -sin advocación-, beneficio de Santiago o San Jaime, beneficio de la Virgen María.

10.- Rectoría de los lugares de Erdas y Centenera. Rectoría o benclicio curado de la Parroquial de Santa Cecilia del lugar de Tortosa. Curato de Viacamp. Y capellanía del Puente de Monzón.

11.- Benelicio de San Francisco y San Juan en la Iglesia Parroquial de San Pedro de Barcelona. Y capellanía en la Parroquia de Nuestra Señora del Pino de Barcelona.

12.- Beneficio de Nuestra Señora en el castillo de la ciudad de Tortosa.

13.- Rectoría de la Parroquial de San Cosme y San Damián, del lugar de Cairans.

14.- J. SARRAILH: La España llustrada de la segunda mitad del siglo XVIII, Madrid, 1974, p. 628 . 
15.- A. DOMÍNGUEZ ORTIZ: "Las rentas episcopales de la Corona de Aragón en el siglo XVIII", en J. Nadal y G. Tortella (edit.): A gricultura, comercio colonial y crecimiento económico en la España Contemporánea, Esplugues de Llobregat (Barcelona), 1974, p. 13.

16.- Si ordenamos las mitras catalanas según el criterio de mayor a menor riqueza, tomando como referencia las cantidades cargadas por el rey en pensiones, es decir, la tercera parte de su valor líquido, obtendremos la siguiente escala: Tarragona, Barcelona, Tortosa, Gerona, Urgel, Lérida, Vic y Solsona.

17.- Tras el Concordato de 1753.

18.- W. CALLAHAN, op. cit., p. 48.

19.- J. SARRAILH, op. cit., p. 629.

20.- En otras ocasiones, atendiendo a la cortedad de los recursos de las mitras, el rey no cargaba todo su tercio correspondiente. Es el caso del Obispado de Vic. Por real cédula de 23 de noviembre de 1752 cargó la "moderada cantidad" de 1006 libras catalanas, repartidas del modo siguiente: 666 para la Universidad de Cervera, 100 para el Hospital de la Corona de Aragón en Madrid, 120 para el convento de dominicos de Vic, y otras 120 para Tomás de Elgueta. Cuando podía dotar sus pensiones con 54 más, hasta llegar al tercio (1.060 libras). A. H. N. "Registros del Real Patronato". Libro 281, ff. 294v-296.

21.- En algunas cédulas de nombramiento de obispos aparece la cantidad reservada para pensiones de designación real, y tras ella la frase "que no excede del tercio de su valor líquido".

En algunas ocasiones, los beneficiados no cobraban todo el montante señalado en su pensión por no caber en el tercio del valor líquido reservado para el rey. Es el caso de la pensión de 16.000 reales de vellón señalada por bulas pontificias sobre los frutos y rentas de la misma mitra en favor de la Universidad de Cervera el 23 de octubre de 1747. Al no caber en el tercio más que 11.958 reales de vellón, esta cantidad fue la cobrada por la Universidad, hasta que vacara alguna de las pensiones vitalicias señaladas sobre los frutos y rentas de la mencionada mitra.

En otras, la cantidad que no cabía en la tercera parte era también entregada al beneficiado por medio de la concesión de otra pensión sobre los frutos y rentas de otra mitra o abadía. Esta situación benefició al ex-obispo de Urgel, Jorge Curado. Con la renuncia, el 2 de septiembre de 1745, se reservó para su manutención 15.000 reales de vellón. Al no caber dicha cantidad en la tercera parte del valor líquido de la mitra (porque lo demás estaba impuesto con bulas pontificias a favor de otras personas y comunidades) se cargaron 8.911 sobre Ios frutos y rentas de la Abadía de San Cugat del Vallés, quedando sobre la mitra urgelitana únicamente 6.089 .

22.- Novísima Recopilación, libro I, título XXIII, ley X. "Don Fernando VI por Real orden de 13 de Mayo de 1750. Consentimiento de los nombrados en mitras, al tiempo de su aceptación, para las pensiones impuestas en ellas.

He resuelto, que en adelante, al tiempo que los nombrados en Mitras avisen de su aceptación, se les pida el consentimiento para la pensión que cupiere en la tercera parte de sus valores, y también para la cantidad que excediere de ella y estuviere confirmada por bulas Apostólicas, aunque, por lo que puedan haber baxado los valores, no tenga cabimiento cl exceso en la referida tercia parte: y esta providencia quedará anotada por punto general en la Secretaría del Real Patronato". 
23.- Y también de los abades de los monasterios del Real Patronato. En nuestro caso, los de la Congregación Benedictina Claustral en Cataluña.

24.- A. DOMÍNGUEZ ORTIZ, "Las rentas episcopales...", pp. 14-15.

25.- J. A. PUJOL: La Corona de Aragón en la Cámara de Castilla (1709-1721), Alicante, 1994, p. 181.

26.- Novísima Recopilación, libro I, título XXIII, ley I.

27.- Ibidem, libro I, título XXIII, ley II. Felipe II en las Cortes de Madrid de 1578.

28.- Ibidem, libro I, título XXIII, ley VI. Fernando VI por Reales resoluciones de 25 de Noviembre y 4 de Diciembre de 1754.

29.- Este real decreto aparece en la Novísima Recopilación, libro I, título XXIII, ley VIII, asî como en la documentación manejada, en real cédula de 2 de julio de 1746 (A. H. N. "Registros del Real Patronato". Libro 280, ff. 77-78).

30.- Pongamos como ejemplo la real cédula de 18 de diciembre de 1746 remitida al obispo de Solsona con motivo de cargarle tres pensiones: una para las cuatro dignidades del Real Patronato de la Catedral de Solsona, otra para el Hospital de la Corona de Aragón en Madrid, y la tercera para la Universidad literaria de Cervera. A. H. N. "Registros del Real Patronato". Libro 281, ff. 84v-87.

31.- Real cédula de 11 de julio de 1748. Con motivo del nombramiento del camarista Francisco Díaz Santos Bullón para la mitra barcelonense, el rey le abona todas las cargas, incluido todo lo que corresponde al subsidio y escusado, para sacar la tercera parte del líquido valor de la mitra y repartirlo a su agrado a modo de pensiones. A. H. N. "Registros del Real Patronato". Libro 281, ff. 131 v-134.

32.- Todas las mitras catalanas tienes pensiones señaladas en favor del Hospital, salvo la ilerdense. Todas las pensiones concedidas sobre los frutos y rentas de las abadías son individuales y vitalicias, salvo las cargadas en el Monasterio de Santa María de Ripoll en beneficio del citado Hospital.

33.- Eran perpetuas, y no precisaban la renovación cada 14 años. En las mitras de Tarragona, Barcelona, Gerona, Lérida, Solsona, Urgel y Vic hallamos pensiones cargadas en su favor. Por tanto, era Tortosa la única que no acudía a la Universidad con sus frutos y rentas.

34.- Con pensiones situadas sobre las mitras de Barcelona y Tortosa. Eran pensiones perpetuas renovables cada 14 años.

35.- Pensión perpetua sin renovación cada 14 años, con fecha de 12 de septiembre de 1727 , concedida para mantener dos maestros de teología moral, dos misioneros, y un religioso que predique y confiese a los soldados de la guarnición de aquella ciudad. A. H. N. "Registros del Real Patronato". Libro 280, fl. 200v-202v.

36.- Pensión perpetua renovable cada 14 años. Para la fábrica de la Catedral.

37.- Pensión perpetua renovable cada 14 años.

38.- Pensión perpetua renovable cada 14 años que se cargaba sobre los frutos y rentas de la mitra de Tortosa.

39.- En la mayoría de las ocasiones se trata de clérigos de prima tonsura o de presbíteros de otras diócesis. Hay pensiones para religiosas, como las del monastcrio franciscano de Jerusalén en Barcelona (María Fontana, Eleonor Janed, Magdalena Castella y Antonia Martínez Araujo). O abades, como el de Cardona, que gozó una pensión situada sobre los frutos y rentas de la mitra de Vic. O el capellán de honor, Juan de Bravo, sobre los de la abadía de San Pedro de Besalú. 
40.- El embajador en La Haya.

41.- El caso más claro fue el del obispado de Lérida cuando era ocupado por Francisco de Olaso Hipenza, quien consiguió que el rey cargara pensiones para tres sobrinos suyos: Blas Fernández Olaso -54 ducados y 10 julios en 1722-, Emeterio Hernández - 100 ducados en 1726-, y Próspero Jiménez de Olaso -75 ducados y 5 julios en 1731 -. A. H. N. "Registros del Real Patronato". Libro 280, ff. 151 v-152, ff. 186-187.

42.- Como Bernardo Velarde, obispo de Tortosa, a quien, por resolución a consulta del 22 de abril de 1765, el rey otorgó los 1.170 reales de vellón que quedaban en su real distribución hasta completar la tercera parte que le correspondía. A. H. N. "Registros del Real Patronato". Libro 282, ff. 120-122.

43.- De este tipo es la pensión de 190 ducados concedida el 3 de noviembre de 1747 a Antonio Copons y de Copons -miembro de una ilustre familia-, sobre los frutos y rentas del arzobispado de Tarragona -que en esos momentos ocupaba su hermano, Pedro Copons y de Copons-, en atención a su fidelidad a la causa borbónica en la Guerra de Sucesión. A. H. N. "Registros del Real Patronato". Libro 281, ff. 113v-114v.

44.- J. A. PUJOL, op. cit. Esta idea no aparece en la versión resumida para el Servicio de Publicaciones de la Universidad de Alicante, pero sí en la memoria de licenciatura original, p. 606.

45.- Por resolución a consulta de 4 de febrero de 1693, Carlos II declaró que no se cargasen pensiones a los beneficios curados.

46.- A. H. N. "Registros del Real Patronato". Libro 282, ff. $110 \mathrm{v}-111 \mathrm{v}$.

47.- Ch. HERMANN: L'Eglise d'Espagne sous le patronage royal (1476-1834), Madrid, 1988, pp. 43-44.

48.- Teófanes EGIDO: "El Regalismo y las relaciones Iglesia-Estado en el siglo XVIII", cn R. García-Villoslada (dir.): Historia de la Iglesia en España, t. IV, B.A.C., Madrid, 1979, p. 139.

49.- A. H. N. "Registros del Real Patronato". Libro 280, ff. 261-263, 268-268v, 273v, 276 277, 281-282. Libro 282, ff. 186-187, 189-191, 191v-192, 192-193v, 200v-202v, 206.

50.- A. H. N. "Registros del Real Patronato". Libro 281, ff. 307v-309v.

51.- A. H. N. "Registros del Real Patronato". Libro 282, ff. $109 \mathrm{v}, 122 \mathrm{v}-124,127 \mathrm{v}-130 \mathrm{v}$.

52.- Su patrón fue un lego.

53.- Expidió otra real cédula con el mismo contenido el 2 de agosto de 1763.

54.- A. H. N. "Registros del Real Patronato". Libro 282, ff. 102v-104.

55.- Ley XVII, del título XVII, del libro I de la Novísina Recopilación.

56.- A. H. N. "Registros del Real Patronato". Libro 282, ff. 3-4.

57.- A. H. N. "Registros del Real Patronato". Libro 282, ff. 182v-184v.

58.- El beneficio anexo al Castillo de la Tallada, o los beneficios de la Virgen María, y de San Jaime y San Juan Bautista en la Catedral de Tortosa.

59.- A. H. N. "Registros del Real Patronato". Libro 281, ff. $159 \mathrm{~V}-160$.

60.- W. CALLAHAN, op. cit., pp. 59-60, 66.

61.- Teófanes EGIDO, "El regalismo en España", en J. Pradells y E. La Parra (edit.): Iglesia, sociedad y Estado en España, Francia e Italia (ss. XVIII al XX), Alicante, 1991, p. 212. Convendría investigar con más profundidad los integrantes regalistas actuantes en la hostilidad manifiesta hacia las cofradías. 
62.- Considerando su devoción hacia esta reliquia por ser costumbre y tradición respetada e inveterada que se llevara a la Corte con ocasión de los nacimientos de los príncipes e infantes.

63.- A. H. N. "Registros del Real Patronato". Libro 280, ff. 171-173.

64.- A. H. N. "Registros del Real Patronato". Libro 282, ff. 138-139.

65.- A. H. N. "Registros del Real Patronato". Libro 280, ff. 198-199.

66.- A. H. N. "Registros del Real Patronato". Libro 280, ff. 207-208v.

67.- A. H. N. "Registros del Real Patronato". Libro 280, ff. 233v-236.

68.- A. H. N. "Registros del Real Patronato". Libro 280, ff. 279-280.

69.- A. H. N. "Registros del Real Patronato". Libro 282, ff. $43 \mathrm{v}-44 \mathrm{v}$.

70.- A. H. N. "Registros del Real Patronato". Libro 280, ff. 86-87v.

71.- Ya conocemos el caso de la Congregación Benedictina Claustral Tarraconense Caesaraugustana.

72.- A. H. N. "Registros del Real Patronato". Libro 280, ff. 361-361v.

73.- A. H. N. "Registros del Real Patronato". Libro 282, ff. 159-160.

74.- A. H. N. "Registros del Real Patronato". Libro 280, ff. 89v-91, ff. $210-211$.

75.- La referencia aparece en la Respuesta de los Tres Señores Fiscales del Consejo en el expediente consultivo de las Cartujas de España, Madrid, 1779, p. 301. Citado por J. Izquierdo Martín, J. M. López García y otros en "La reforma de regulares durante el reinado de Carlos III. Una valoración a través del ejemplo madrileño”, en Equipo Madrid: Carlos III, Madrid y la Ilustración, Madrid, 1988, p. 205.

76.- Enrique GIMÉNEZ y otros: Introducción a la Historia Moderna, Madrid, 1991, p. 508 : "La diplomacia británica, tras incluir a Sajonia en el campo austríaco, supo convencer a Carlos Manuel III de Saboya, oficialmente aliado de Francia, para que se uniera a Austria a cambio de la cesión por ésta de una parte de la Lombardía, el ducado de Plasencia y el marquesado de Finale. El Tratado de Worms, en septiembre de 1743, entre Austria y Saboya certificaba la nueva alianza y abría un nuevo frente en Italia. Al finalizar 1743, Francia se hallaba aislada, con sólo el apoyo de España, con la que había suscrito el 18 de octubre el segundo Pacto de Familia”.

77.- A. H. N. "Registros del Real Patronato". Libro 280, lf. 338-339. Tampoco se vio nunca bien en los círculos de la monarquía el que los prelados españoles salieran del país para acudir a capítulos generales, por la doble pérdida que suponía: de control sobre sus órdenes; y de rentas, que fluían hacia las casas matrices.

78.- A. H. N. "Registros del Real Patronato". Libro 281, ff. 319-319v.Esta actuación real se inscribe dentro del programa de reforma del clero regular. Según Jesús IZQUIERDO MARTÍN, José Miguel LÓPEZ GARCÍA y otros, en "La relorma de regulares durante el reinado de Carlos III. Una valoración a través del ejemplo madrileño", del libro del Equipo Madrid: Carlos III, Madrid y la Ilustración, Madrid, 1988, p. 205, la reforma de los regulares hacía hincapié en tres aspectos fundamentales: el aumento del control real sobre las congregaciones hispanas, la paralización del proceso de amortización con sus consiguicntes electos positivos sobre los ingresos de la Hacienda Real, y la dignilicación de los miembros de las órdenes monásticas -que es lo que pretende Fernando VI con la designación del obispo de Vic-. 
79.- A. H. N. "Registros del Real Patronato". Libro 280, ff, 161v-162v.

80.- A. H. N. "Registros del Real Patronato". Libro 282, ff. $45 \mathrm{v}-46$.

81.- A. H. N. "Registros del Real Patronato". Libro 280, ff. 175-176v.

82.- A. H. N. "Registros del Real Patronato". Libro 282, ff. 177-178v.

83.- A. H. N. "Registros del Real Patronato". Libro 282, ff. 204-205.

84.- A. H. N. "Registros del Real Patronato". Libro 282, ff. $212 v-214$.

85.- El ideal del movimiento reformista era una religión intelectual en la que el fiel entendiera las verdades de la fe, practicara la liturgia con sencillez y avanzara por el camino de la perfección espiritual y temporal. En W. CALLAHAN, op. cit., p. 74.

86.- Ya pudimos comprobar que Felipe $\mathrm{V}$, mediante la instauración de las canonjías de oficio en las catedrales catalanas, perseguía una mejor dotación intelectual del clero capitular para cubrir más adecuadamente las necesidades y los problemas espirituales de sus católicos súbditos.

87.- W. CALLAHAN, op. cit., pp. 14, 25, 26. A. DOMÍNGUEZ ORTIZ, Sociedad y Estado en el siglo XVIII español, Madrid, 1976, p. 373.

88.- W. CALLAHAN, op. cit., p. 38. J. SARRAILH, en La España Ilustrada de la segunda mitad del siglo XVIII, Madrid, 1974, p. 629, ofrece otra explicación de la expulsión de la Compañía. Alude al interés de Carlos III por recuperar una porción importante de las posesiones del clero. De ahí que, tras la expulsión de los jesuitas, se decretara la secularización de los bienes de la Compañía y el empleo de sus inmuebles para obras públicas.

89.- A. H. N. "Registros del Real Patronato". Libro 282, ff. 160v-165v.

90.- A. H. N. "Registros del Real Patronato". Libro 282, f. 208.

91.- A. H. N. "Registros del Real Patronato". Libro 282, ff. 150-152v.

92.- A. H. N. "Registros del Real Patronato". Libro 282, f. 210.

93.- A. H. N. "Registros del Real Patronato". Libro 281, ff. 176v-179.

94.- W. CALLAHAN, op. cit., p. 12, 58.

95.- Esta necesidad de trabajar iría marcándose progresivamente en su personalidad, forjándose a lo largo del siglo "el estereotipo del catalán laborioso y emprendedor, al que se admira y a la par se considera con cierta aprension". En A. DOMíNGUEZ ORTIZ, Sociedad y Estado..., p. 247.

96.- A. H. N. "Registros del Real Patronato". Libro 280, ff. $211 \mathrm{v}-212 \mathrm{v}$.

97.- T. EGIDO, "El regalismo en España", en J. Pradells y E. La Parra (edil.): Iglesia, sociedad y Estado en España, Francia e Italia (ss. XVIII al XX), Alicante, 1991, p. 212.

98.- En el fondo -como se dice explícitamente en el Discurso sobre el fomento de la industria popular (1774) que el Fiscal de Castilla se encargó de divulgar- todo se subordinaba a cálculos más realistas: "Para calcular la pérdida de jornales que ocasiona el excesivo número de fiestas de precepto eclesiástico, con sólo suponer ocho millones de habitantes trabajadores de ambos sexos, y que una persona con otra gane dos reales de jornal, cada fiesta de precepto reducida o trasladada al domingo producirá en España diez y seis millones de reales de utilidad y la proporción correspondiente en manufacturas o en mayor extensión de la agricultura. En Alemania se trabaja actualmente en reducir los días festivos". En T. Egido, "Actitudes religiosas de los ilustrados españoles", en Carlos III y la llustración, tomo I, Madric, 1988, pp. 233-234. 
99.- Los abades de los monasterios de San Cugat del Vallés, Santa María de Montserrat, y Nuestra Señora de Poblet; y los prelados de las mitras de Tarragona, Barcelona y Urgel. 100.- W. CALLAHAN, op. cit., p. 16.

101.- A. H. N. "Registros del Real Patronato". Libro 280, ff. 125-126.

102.- A. H. N. "Registros del Real Patronato". Libro 280, ff. 159v-161, ff. 179v-182.

103.- A. H. N. "Registros del Real Patronato". Libro 282, ff. $131 \mathrm{v}-134$.

104.- A. H. N. "Registros del Real Patronato". Libro 282, ff. 141-148.

105.- A. H. N. "Registros del Real Patronato". Libro 282, f. 149.

106.- A. H. N. "Registros del Real Patronato". Libro 282, ff. 184v-186.

107.- A. H. N. "Registros del Real Patronato". Libro 282, ff. 211 v-212v. 